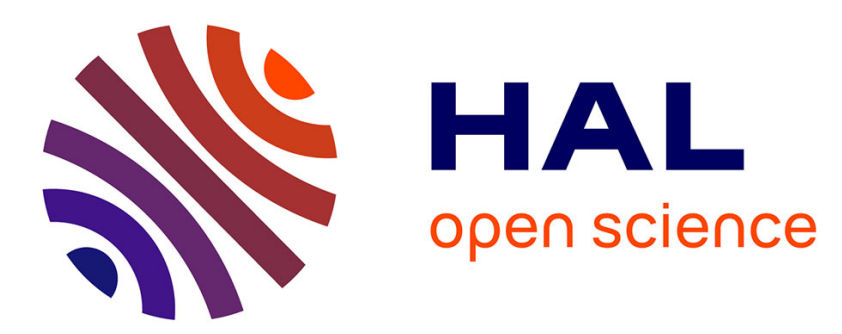

\title{
Influence of various parameters on heat-induced internal sulphate attack
}

\author{
Ali-Nordine Leklou, Jean-Emmanuel Aubert, Gilles Escadeillas
}

\section{To cite this version:}

Ali-Nordine Leklou, Jean-Emmanuel Aubert, Gilles Escadeillas. Influence of various parameters on heat-induced internal sulphate attack. European Journal of Environmental and Civil Engineering, 2013, 17 (3), pp.141-153. 10.1080/19648189.2012.755338 . hal-01006981

\section{HAL Id: hal-01006981 \\ https://hal.science/hal-01006981}

Submitted on 4 May 2018

HAL is a multi-disciplinary open access archive for the deposit and dissemination of scientific research documents, whether they are published or not. The documents may come from teaching and research institutions in France or abroad, or from public or private research centers.
L'archive ouverte pluridisciplinaire HAL, est destinée au dépôt et à la diffusion de documents scientifiques de niveau recherche, publiés ou non, émanant des établissements d'enseignement et de recherche français ou étrangers, des laboratoires publics ou privés. 


\title{
Influence of various parameters on heat-induced internal sulphate attack
}

\author{
Nordine Leklou ${ }^{\mathrm{a} *}$, Jean-Emmanuel Aubert ${ }^{\mathrm{b}}$ and Gilles Escadeillas ${ }^{\mathrm{b}}$ \\ ${ }^{a}$ GeM, UMR CNRS 6183 - Research Institute on Civil Engineering and Mechanics, IUT Saint- \\ Nazaire, LUNAM Université, Université de Nantes - POLYTECH NANTES, Saint-Nazaire Cedex, \\ France; ${ }^{b}$ LMDC (Laboratoire Matériaux et Durabilité des Constructions), INSA, UPS, Université \\ de Toulouse, Toulouse Cedex, France
}

The work presented in this article studies the effects of some parameters that can be considered, a priori, as important in the appearance of delayed ettringite formation (DEF). The parameters studied are the nature of the binder, the water/cement (W/C) ratio, the preliminary microcracking (wetting-drying cycles) and the curing conditions. The results presented show that the chemical composition of cement is one of the main parameters controlling the appearance of DEF. The other parameters studied, (W/C ratio, wetting-drying cycles and temperature of curing water) principally modify the kinetics of the expansion: it seems that, the more favourable the conditions are to ionic and hydrous transfers, the sooner the expansion starts. Finally, the renewal of the curing water strongly affects the start of DEF. In one case of the study, the renewal of the curing water only accelerated the start of the expansion. In the second, it led to late starting of DEF (four years) whereas the same mixture cured continuously in water that was not renewed still had not expanded after more than five years.

L'étude présentée dans cet article a pour objectif d'observer les effets de certains paramètres que l'on peut qualifier a priori d'importants vis-à-vis de l'apparition de la DEF. Les paramètres étudiés sont la nature du liant, le rapport E/C des mélanges, le préendommagement des éprouvettes (cycles d'humidification-séchage) et, enfin, les conditions de conservation des échantillons. Les résultats présentés montrent que la composition chimique du ciment est l'un des principaux paramètres contrôlant l'apparition de la DEF. Les autres paramètres étudiés (rapport E/C, cycles d'humidification-séchage et la température de l'eau de conservation des échantillons), modifient principalement la cinétique de l'expansion: il semble que plus les conditions sont favorables pour améliorer les transferts ioniques et hydriques, plus l'apparition des expansions est accélérée. Enfin, le renouvellement de l'eau de conservation affecte fortement le début de l'apparition de la DEF. Dans un cas d'étude, il n'a fait qu'accélérer le début de l'expansion. Dans un second cas, le renouvellement de l'eau de conservation a permis le déclenchement de la DEF au bout de 4 ans, alors que le même mélange conservé en permanence dans l'eau qui n'a pas été renouvelé n'avait pas encore montré de gonflement après plus de 5 ans.

Keywords: delayed ettringite formation (DEF); expansion; swelling; sulphate attack; mortars

Mots-clés: formation d'Ettringite Différée; expansion; gonflement; attaque sulfatique; mortiers

*Corresponding author. Email: nordine.leklou@univ-nantes.fr 


\section{Introduction}

Heat-induced internal sulphate attack (still commonly referred to as delayed ettringite formation $[\mathrm{DEF}]$ ) is a chemical reaction observed in hardened cement mortars and concrete exposed to excessive temperatures at early ages. The result of this pathology is an expansion due to the DEF without an external source of sulphate (Heinz \& Ludwig, 1985; Taylor, Famy, \& Scrivener, 2001). Many years of research on heat-induced internal sulphate attack has led to a consensus on numerous points concerning this pathology and, especially, on the effect of some parameters. The main conclusions of this research were summarised during the RILEM workshop on Internal Sulphate Attack and DEF (Scrivener \& Skalny, 2005). According to the literature, the main parameters affecting this pathology can be described as follows.

Temperature and duration of thermal treatment: all authors agree that the temperature and duration of thermal treatment strongly influence the expansion due to DEF (Brown \& Bothe, 1993; Brunetaud, 2005; Escadeillas, Aubert, Segerer, \& Prince, 2007; Famy, 1999; Kelham, 1999; Moranville, 1995; Scrivener \& Lewis, 1999). For a long time, researchers have tried to determine the temperature from which the risk of appearance of DEF was to be envisaged. Today, it seems that a consensus has been reached on a value of $70^{\circ} \mathrm{C}$ even though, a study on field concrete showed that heat-induced internal sulphate attack developed in concrete whose temperature had not exceeded $60^{\circ} \mathrm{C}$ (Sahu \& Thaulow, 2004). Brunetaud, Linder, Divet, Duragrin and Damidot (2007) have studied many experimental designs to organise the parameters and interactions between parameters that affect DEF-related expansions into a hierarchy. They have shown that the most relevant parameters affecting DEF are (in decreasing order) the coupling between temperature and duration and the individual effects of duration and temperature. In particular, they have shown that, by heating at $65^{\circ} \mathrm{C}$, an increase in duration increases DEF-related risks, if any. However, by heating at $85^{\circ} \mathrm{C}$, the risks of expansion increase from $2 \mathrm{~h}$ to 2 days but decrease thereafter. Thus, there is a pessimum effect that mostly depends on the coupling between temperature and duration. It should be pointed out that the literature does not mention cases of a decrease in sensitivity with respect to DEF resulting from an increase in temperature and that could very well be due to the fact that the duration of the heat treatment is rarely maintained, for as long as 10 days.

Exposure to water: the pioneering works of Heinz and Ludwig (1985) showed that no expansion was observed below $90 \%$ of relative humidity. Other works have confirmed these results and it is now considered that minimal conditions of relative humidity are necessary for the development of this pathology and that the expansion is greater when more water is available (Aubert, Escadeillas, \& Leklou, 2009; Collepardi, 1999; Famy, Scrivener, Atkinson, \& Brough, 2001; Odler \& Chen, 1995).

Cement characteristics: the sulphates and the aluminates contained in the cement have to be present in sufficient quantities to permit the formation of the delayed ettringite. So, according to some authors, DEF is essentially observed for materials prepared with high $\mathrm{C}_{3} \mathrm{~A}$ (higher than 10\%) and high $\mathrm{SO}_{3}$ (higher than $3 \%$ ) cements (Odler \& Chen, 1995; Kelham, 1996). Moreover, the majority of researchers working on this subject are unanimous today on the essential role played by alkalis on the development of DEF and on the ultimate value of the expansion (Heinz, Kalde, Ludwig, \& Ruediger, 1999; Hime \& Marusin, 1999; Pavoine, 2003). It has been demonstrated that an increase in the alkali content combined with the effect of temperature leads to a higher solubility of the ettringite and thus to easier decomposition of early ettringite (Divet \& Randriambololona, 1998; Ghorab, 1999). 
Fineness of the cement: many studies have shown a correlation between the fineness of the cement and DEF. The finer the cement, the greater the amount of DEF (Fu, Ding, \& Beaudoin, 1997; Heinz et al., 1999; Kelham, 1996).

Mineral admixtures: some studies have been carried out on the effect of mineral admixtures on the appearance of DEF. Generally, it seems that the addition of ground granulated blast furnace slag, fly ash or metakaolin decreases the expansion caused by DEF (Grattan-Bellew, Beaudoin, \& Vallée, 1998; Ramlochan, Thomas, \& Hooton, 2004; Ramlochan, Zacarias, Thomas, \& Hooton, 2003). The mechanisms have not been completely elucidated but these studies seem to show that, depending on their type, mineral admixtures could have an effect on DEF by modifying the chemical pore solution or its $\mathrm{pH}$, or because of the nature of the $\mathrm{C}-\mathrm{S}-\mathrm{H}$ formed.

Aggregate characteristics: the composition of the aggregate plays a significant role in the expansions caused by DEF (Fu et al., 1997; Ramlochan et al., 2003; Yang, Lawrence, \& Sharp, 1999). Siliceous aggregates lead to higher expansion than that observed with limestone aggregates. Moreover, it seems that, the smaller the aggregate particle size, the higher the expansion (Fu et al., 1997; Yang et al., 1999).

Water/cement ratio: the results dealing with the effect of the water/cement (W/C) ratio on DEF are sometimes contradictory. According to the interpretations of Stark and Bollmann (1992), a decrease in the W/C ratio would decrease the space available for the formation of ettringite, which would lead to higher expansion. This was confirmed by the results of Petrov (2003) showing that decreasing the $\mathrm{W} / \mathrm{C}$ ratio significantly slowed down the expansions caused by DEF and increased the ultimate value of the expansion. In contrast, Ouyang, Nanni, and Chang (1988) observed that decreasing the $\mathrm{W} / \mathrm{C}$ ratio improved resistance to internal sulphate attack because of the reduction in hydrous and ionic transfers due to the lower porosity.

Preliminary microcracking: many authors think that preliminary microcracking of the samples is necessary for the appearance of DEF (Collepardi, 1997; Fu, Xie, Gu, \& Beaudoin, 1994). Others believe that microcracking of the material increases the kinetics and the amplitude of the degradation during the formation of delayed ettringite but that microcraking is not necessary for the appearance of this pathology (Escadeillas et al., 2007; Leklou, Aubert, \& Escadeillas, 2009; Pavoine, 2003; Petrov \& Tagnit-Hamou, 2004).

This synthetic review of the literature shows that, in spite of many years of research, some questions related to the appearance and development of this pathology remain, in particular the role played by certain parameters. It is thus still necessary to pursue research for a better understanding of this pathology. The work presented in this article studies the effects of some parameters that can be considered as important a priori in the appearance of DEF. The parameters studied are the nature of the binder, the $\mathrm{W} / \mathrm{C}$ ratio, preliminary microcracking and, finally, the curing conditions. It is important to note that none of the mixtures tested without heat curing expanded, even the mixtures rich in sulphate (in the cases of $\mathrm{Na}_{2} \mathrm{SO}_{4}$ addition). This article will thus only present the results of the mixtures susceptible to DEF i.e. those that are heat-cured during their first hours of hydration.

\section{Experiments}

\subsection{Materials}

Three ordinary Portland cements were used in this study (CEM I 52.5 R type according to the NF EN 197-1 standard, comparable to ASTM Type III cement). The chemical analyses of these three cements are given in Table 1 together with the phase compositions 
Table 1. Chemical and mineralogical composition of the cements (\% w/w).

\begin{tabular}{lccc}
\hline Cement & $\begin{array}{c}\text { "A" } \\
\text { content (\%) }\end{array}$ & $\begin{array}{c}\text { "B" } \\
\text { content (\%) }\end{array}$ & $\begin{array}{c}\text { "C" } \\
\text { content (\%) }\end{array}$ \\
\hline $\mathrm{SiO}_{2}$ & 19.9 & 19.3 & 22.2 \\
$\mathrm{Al}_{2} \mathrm{O}_{3}$ & 4.0 & 4.6 & 2.8 \\
$\mathrm{Fe}_{2} \mathrm{O}_{3}$ & 3.3 & 2.2 & 2.1 \\
$\mathrm{CaO}$ & 63.4 & 63.9 & 66.4 \\
$\mathrm{MgO}$ & 1.7 & 2.4 & .6 \\
$\mathrm{SO}_{3}$ & 3.2 & 3.3 & 2.3 \\
$\mathrm{~K}_{2} \mathrm{O}$ & 1.2 & 1.1 & .2 \\
$\mathrm{Na}_{2} \mathrm{O}$ & .6 & .3 & .4 \\
${\mathrm{Equivalent} \mathrm{Na}_{2} \mathrm{O}}_{\mathrm{C}_{3} \mathrm{~S} \text { Bogue }}$ & 1.4 & 1.0 & .5 \\
$\mathrm{C}_{2} \mathrm{~S}$ Bogue & 53.1 & 90.0 & 64.0 \\
$\mathrm{C}_{3}$ A Bogue & 15.3 & 10.1 & 15.6 \\
$\mathrm{C}_{4}$ AF Bogue & 6.9 & 7.3 & 3.9 \\
\hline
\end{tabular}

from Bogue calculation. The cement referred to as " $\mathrm{A}$ " had high $\mathrm{K}_{2} \mathrm{O}$ and $\mathrm{Na}_{2} \mathrm{O}$ contents and a usual $\mathrm{C}_{3} \mathrm{~A}$ content; cement " $\mathrm{B}$ " had a high $\mathrm{C}_{3} \mathrm{~A}$ content and cement " $\mathrm{C}$ " was low alkali and low $\mathrm{C}_{3} \mathrm{~A}$ cement. To accelerate and amplify the appearance of the phenomenon, $3.1 \%$ (by weight of cement) of $\mathrm{Na}_{2} \mathrm{SO}_{4}$ was added to some mixtures. In such cases, the letter " $\mathrm{S}$ " has been added to the name of the binder used (for example, "BS" is a mix of cement " $\mathrm{B}$ " and $\mathrm{Na}_{2} \mathrm{SO}_{4}$ ). Sodium sulphate was a pure commercial product and its fineness was also comparable to that of the cement.

The siliceous aggregate was a French sand meeting standard NF EN 196-1. This aggregate is classified as non-reactive with respect to alkali-silica reaction by NF-P 18590. The siliceous aggregate was chosen because it leads to faster expansion than limestone sand (Fu et al., 1997; Grattan-Bellew et al., 1998; Yang et al., 1999).

The mortars (3:1:.5 sand:cement:water) were prepared according to standard NF EN 196-1. The mortar prisms were cast in $40 \times 40 \times 160 \mathrm{~mm}$ metallic moulds. The mortar samples were cured directly in their moulds, equipped with embedded length measurement studs. During the thermal treatment, the moulds were covered with a metallic plate to limit water exchange.

\subsection{Procedures}

\subsubsection{Heat treatment}

After casting, the mortar specimens were cured according to a heat treatment that followed a cycle that is divided into four different phases:

- Phase No. 1: pre-cure at $20^{\circ} \mathrm{C}$ for $1 \mathrm{~h}$.

- Phase No. 2: temperature rise at $20^{\circ} \mathrm{C} / \mathrm{h}$.

- Phase No. 3: temperature plateau at $80^{\circ} \mathrm{C}$ for $10 \mathrm{~h}$.

- Phase No. 4: return to ambient temperature (about $20^{\circ} \mathrm{C}$ ), at $20^{\circ} \mathrm{C} / \mathrm{h}$.

This heat treatment was in accordance with LCPC method no. 66 (LCPC, 2007). The specimens were placed in a drying oven equipped with a temperature controller. Thermocouples were placed in the control specimen to verify the temperatures that reached during the treatment. After cooling, the prisms were demoulded and stored in 
water at $20^{\circ} \mathrm{C}$. Three specimens $(4 \times 4 \times 16 \mathrm{~cm})$ of each composition were conserved in closed tanks $(20 \times 20 \times 10 \mathrm{~cm})$ filled with water that was not renewed.

\subsubsection{Test procedure}

Expansion measurements were performed with an extensometer having an accuracy of $1 \mu \mathrm{m}(\operatorname{mortar} 6 \mu \mathrm{m} / \mathrm{cm})$. The frequency of these measurements was high during the period of maximum speed of expansion (weekly) and decreased when the speed of expansion was low (monthly). Each point on the graph is derived from the average calculated on expansions of three specimens. For the expansion measurements, time zero was day 1 after the demoulding of the specimens.

\subsubsection{Parameters studied}

Nature of the binder: this part of the study dealt with the behaviour of mortar prisms prepared with different binders. All the mortars had the same W/C ratio (.50) and they were cured in water at $20^{\circ} \mathrm{C}$ that was not renewed. Here, it was the susceptibility of the binder to DEF that was studied.

$W / C$ ratio: to study the effect of the $\mathrm{W} / \mathrm{C}$ ratio, and consequently of the porosity, on the expansion within a reasonable time; a series of samples composed of BS cement and having a $\mathrm{W} / \mathrm{C}$ ratio equal to $.50, .55$ and .60 were prepared. These mortars were cured in water at $20^{\circ} \mathrm{C}$ that was not renewed.

Wetting-drying cycles: the effects of wetting-drying cycles on the appearance and the development of DEF were studied in order to answer the following two main questions: is preliminary microcracking necessary for DEF and does preliminary microcracking have an effect on the kinetics of development of this pathology? For this part of the work, 14 days after demoulding, half the specimens were stored in water at $20^{\circ} \mathrm{C}$, while the other half underwent 10 wetting-drying cycles (five days in water at $20^{\circ} \mathrm{C}$ followed by two days in a drying oven at $50^{\circ} \mathrm{C}$ ). In both cases, the storage water was not renewed during the tests.

Storage conditions: the effects of the storage conditions on the appearance and the development of DEF were studied through two parameters: the temperature of the curing water and the renewal or not of this water. A series of mortars composed of BS cement and having a W/C ratio of .55 were prepared. Three series of three specimens were placed in water that was not renewed at different temperatures: 20,40 and $60^{\circ} \mathrm{C}$. Another series of three specimens were cured in frequently renewed water (RW) at $20^{\circ} \mathrm{C}$. In this case, the water was renewed at each measurement of the expansion.

Nomenclature of the specimens: the following nomenclature will be used to facilitate discussion of the results:

- the specimens containing sodium sulphate are called BS and CS, and those containing only cement are called $\mathrm{A}, \mathrm{B}$ and $\mathrm{C}$ according to the binder used;

- the $\mathrm{W} / \mathrm{C}$ ratio of the specimens is indicated by $50(\mathrm{~W} / \mathrm{C}=.50), 55$ or 60 ;

- the temperature of the storage water is indicated by 20,40 or 60 ;

- the curing conditions are indicated by the following letters: no letter in the case where the water was not renewed, "RW" for renewed water and "WD" for the specimens subjected to the wetting-drying cycles; and

- when the results of two specimens are presented, a number is given to each specimen to distinguish them (e.g. "(1)" or "(2)"). 


\section{Results}

\subsection{Effects of the nature of the binder}

The length variations of the five mortars (A, B, C, BS and CS) are presented in Figure 1. The following comments can be made after an analysis of the curves of Figure 1.

Concerning the effect of the nature of the cement on the appearance of swelling, of the three cements studied, only cement A, which contained large amounts of alkali and sulphate and which was thus assumed to be favourable to DEF, showed a little expansion at a very late date $(.04 \%$ at 950 days). The other two mortars prepared with cements $\mathrm{B}$ and $\mathrm{C}$, although cured with the same heat treatment at $80^{\circ} \mathrm{C}$, did not show swelling after more than 1000 days.

The difference between cements A and B is interesting. These two cements have rather similar characteristics (chemical composition and specific area), the most significant difference between them being their alkali contents $\left(\mathrm{Na}_{2} \mathrm{O}_{\text {eq }}\right.$ equal to $1.4 \%$ for cement $\mathrm{A}$ and $1.0 \%$ for cement $\mathrm{B}$ ). This seems to confirm that, with equivalent $\mathrm{Al}_{2} \mathrm{O}_{3}$ and $\mathrm{SO}_{3}$ contents, the alkali content is an important parameter in the appearance of DEF. Moreover, significant differences between cements $\mathrm{A}$ and $\mathrm{B}$ could also be observed for $\mathrm{Fe}_{2} \mathrm{O}_{3}$ and $\mathrm{MgO}$ but the role of these two oxides on DEF is not fully elucidated. Taylor et al. (2001) suggested that a tendency was observed for expansion with an increase in $\mathrm{MgO}$ content but that was not the case here.

For cement $\mathrm{C}$, the very low $\mathrm{C}_{3} \mathrm{~A}$ content $(3.9 \%)$ could explain its non-reactivity. Moreover, this cement contained very little alkali $\left(\mathrm{Na}_{2} \mathrm{O}_{\mathrm{eq}}=.5 \%\right)$, and this could also increase its resistance to DEF.

Concerning the effect of $\mathrm{Na}_{2} \mathrm{SO}_{4}$ addition on the appearance of swelling, both the BS and CS cements showed fast, large swelling. Two differences are observable in the behaviour of these two cements: the evolution of swelling (see following comment) and the amplitude of swelling. For the same amount of added $\mathrm{Na}_{2} \mathrm{SO}_{4}$, the cement richest in $\mathrm{C}_{3} \mathrm{~A}$ (BS cement) was the one for which swelling was the most marked. In all cases, the addition of $\mathrm{Na}_{2} \mathrm{SO}_{4}$ induced the appearance of expansion attributable to DEF, even for cement $\mathrm{C}$, which was low in $\mathrm{C}_{3} \mathrm{~A}$. These results show that the $\mathrm{C}_{3} \mathrm{~A}$ content affects the amplitude of expansion of DEF-affected samples but it is not a limiting factor for the appearance of this pathology. It is thus possible for low- $\mathrm{C}_{3} \mathrm{~A}$ cements to develop DEF if the other parameters necessary to its development are present (raised temperature of the heat treatment, presence of moisture, high $\mathrm{SO}_{3}$ and alkali contents).

Concerning the evolution of expansion, the curve of the mortar made with BS cement shows a clear acceleration nearly .1\% and then stabilizes with an ultimate expansion equal to $1.8 \%$. This type of swelling with a sigmoid shape is noted in many works. The curve of the mortar prepared with CS cement presents slow, linear expansion which remains below .6\% after 800 days. This type of expansion was also observed in the work of Brunetaud (2005).

\subsection{Effects of the $W / C$ ratio}

The length variations of the BS mortars prepared with different W/C ratios are presented in Figure 2.

The results in Figure 2 show that the increase in the W/C ratio of mortars $(\mathrm{W} / \mathrm{C}>.50)$ significantly accelerates the appearance of expansion. Moreover, the higher the $\mathrm{W} / \mathrm{C}$ ratio, the sooner the expansion appears. These results are in agreement with 


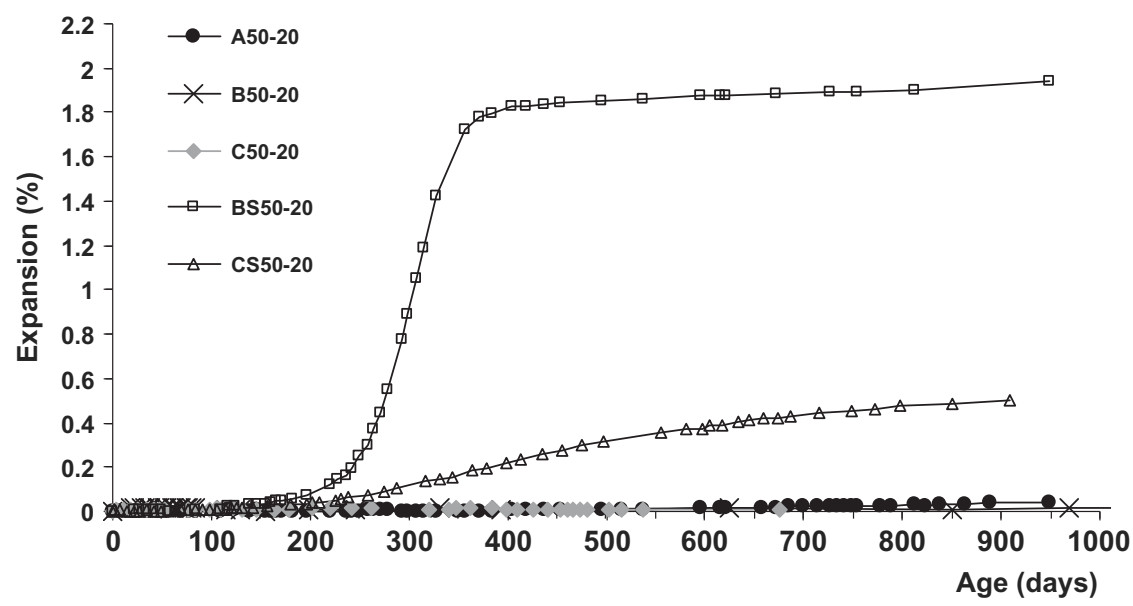

Figure 1. Length variations of the mortars A, B, C, BS and CS.

those of Petrov (2003). However, it seems that the ultimate value of expansion is independent of $\mathrm{W} / \mathrm{C}$ ratio (for $\mathrm{W} / \mathrm{C}$ ratios ranging between .50 and .60). This appears to indicate that the amount of expansive ettringite associated with the ultimate expansions is independent of the W/C ratio and so only depends on the reagents involved $\left(\mathrm{C}_{3} \mathrm{~A}\right.$, sulphate and alkali contents). In his Ph.D. thesis, Petrov (2003) shows that the increase of porosity due to the use of an air-entraining agent absorbs a part of the expansion related to DEF and, consequently, reduces the expansion. Here, the increase in porosity due to the increase in the $\mathrm{W} / \mathrm{C}$ ratio seems to be too weak to be able to absorb the expansions induced by the DEF.

Concerning the acceleration of the expansion with the increase in the $\mathrm{W} / \mathrm{C}$ ratio, it is possible to find several explanations for this phenomenon:

- The increase in the $\mathrm{W} / \mathrm{C}$ ratio weakens the cement paste. According to the mechanism proposed by Brunetaud (2005), the uniform expansion of the cement paste due to DEF (latent period) induces pressures in the material that generate or do not generate cracks according to its resistance. The development of cracks accelerates the expansion of the material and corresponds to the second phase of the mechanism (acceleration of expansion). So, according to this mechanism, the more resistant the cement paste is, the longer it takes to pass on to the phase during which high expansion will occur (and conversely).

- The increase in the $\mathrm{W} / \mathrm{C}$ ratio leads to an increase in the porosity, the consequence of which is an increase in hydrous and ionic transfers. These ionic transfers can play different roles in the appearance and development of DEF. First, the increase of the mobility of aluminate and sulphate ions contained in the material supports the formation of ettringite. Secondly, the increase in ionic transfers accelerates the leaching of alkalis, which modifies the chemical balance of the pore solution by decreasing the concentration of alkalis. This decrease of alkalis in the pore solution (and consequently its $\mathrm{pH}$ ) supports the desorption of sulphates from the CSH as shown by Divet (2001). This is favourable for the formation of ettringite. 


\subsection{Effects of the wetting-drying cycles}

The length variations of the mortars BS50 subjected to the wetting-drying cycles are presented in Figure 3 and compared with the length variations of specimens continuously cured in water.

The results in Figure 3 show that the preliminary microcracking induced by the wetting-drying cycles significantly accelerates the appearance of expansion. This result is in accordance with those obtained by other researchers (Leklou, Aubert, \& Escadeillas, 2012; Leklou et al., 2009; Pavoine, 2003; Petrov, 2003; Petrov \& Tagnit-Hamou, 2004). The explanation for this acceleration may be the same as that for the effect of the W/C ratio: the microcracking induced by the wetting-drying cycles weakens the cement paste, on the one hand, and increases the ionic and hydrous transfers on the other. Finally, the results confirm that the cracking of the samples is not a necessary condition for DEF since it also develops (but later) in mortars continuously cured in water and, also, without preliminary microcracking. These observations confirm those published by Escadeillas et al. (2007).

\subsection{Effects of temperature of curing water}

Figure 4 presents the length variations of the BS55 mortar stored in water at different temperatures.

The beginning of the expansion is accelerated when the cure temperature increases from 20 to $40^{\circ} \mathrm{C}$. During the preceding discussions of the other parameters studied, the modifications of hydrous and ionic transfers were regularly quoted to explain the results obtained. The effect of the increase in the cure temperature on the ionic transfers (diffusion and leaching of some elements) leads to similar interpretations. Many studies have shown that higher temperatures significantly accelerate the diffusion of the elements contained in the pore solution, the majority of the authors modelling the effect of the temperature on the diffusion coefficient with an Arrhenius law, i.e. with an exponential effect of the temperature. Also, an increase in the cure temperature accelerates the leaching of the alkalis. This would make it possible to destabilise chemical balances

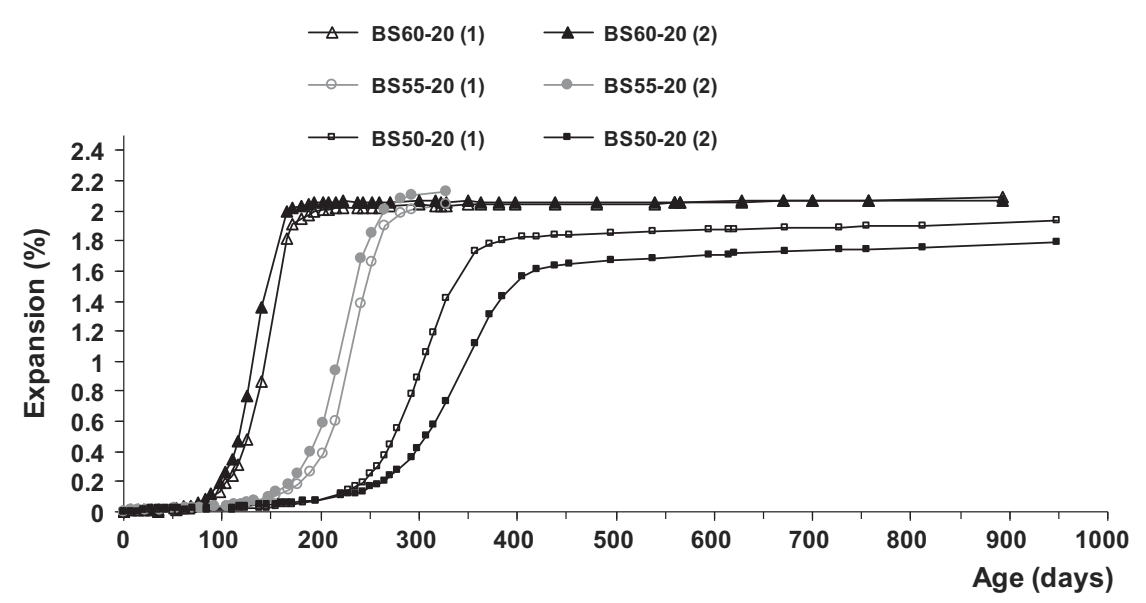

Figure 2. Length variations of mortars prepared with BS cement and having different W/C ratios. 
between sulphates adsorbed on $\mathrm{CSH}$ and the pore solution faster, and thus accelerate the formation of secondary ettringite.

Contrary to the acceleration observed for a temperature of $40{ }^{\circ} \mathrm{C}$, curing the specimens at $60{ }^{\circ} \mathrm{C}$ does not accelerate the formation of delayed ettringite. Also, although the results are not sufficiently advanced to conclude, it seems that the ettringite formation is further delayed or even prevented. This is undoubtedly due to the fact that this temperature is close to that of instability of ettringite, which thus cannot be formed (Damidot \& Glasser, 1992, 1993).

The results obtained are in agreement with those of Petrov (2003) although the two approaches are different. Petrov worked on the influence of thermal cycles of curing water on the appearance of DEF. In these experiments, the water temperature varied from 10 to $50{ }^{\circ} \mathrm{C}$ at a rate of six cycles per day. The results obtained by Petrov show that these cycles accelerate the beginning of the expansion, which is confirmed by the results presented in Figure 4. However, the author does not justify the need for these cycles (except to simulate the temperature variations of a hot climate) or the role they play in the acceleration of the expansion. Seeing the results presented in this article, it is possible to consider that constant immersion in water at $50^{\circ} \mathrm{C}$ would have an accelerating effect at least as great as the use of temperature cycles varying from 10 to $50^{\circ} \mathrm{C}$.

\subsection{Effect of the renewal of curing water}

The length variations of B50 and BS55 mortars stored in RW are presented in Figure 5 and compared with the length variations of specimens continuously cured in unchanged water.

In the case of the B50 mortars, the renewal of the curing water involved the late appearance of expansion (after more than three years). Scanning electron microscopy observations of mortars B50-20RW showed that this expansion was ascribable to DEF. These same mortars cured continuously in water have not expanded after five years. It is too early to know if the water renewal caused the DEF in this mixture or if the modifications of curing conditions only accelerated the appearance of the phenomena (which will be the case if the B50-20 mortar expands one day). In the case of the BS mortars,

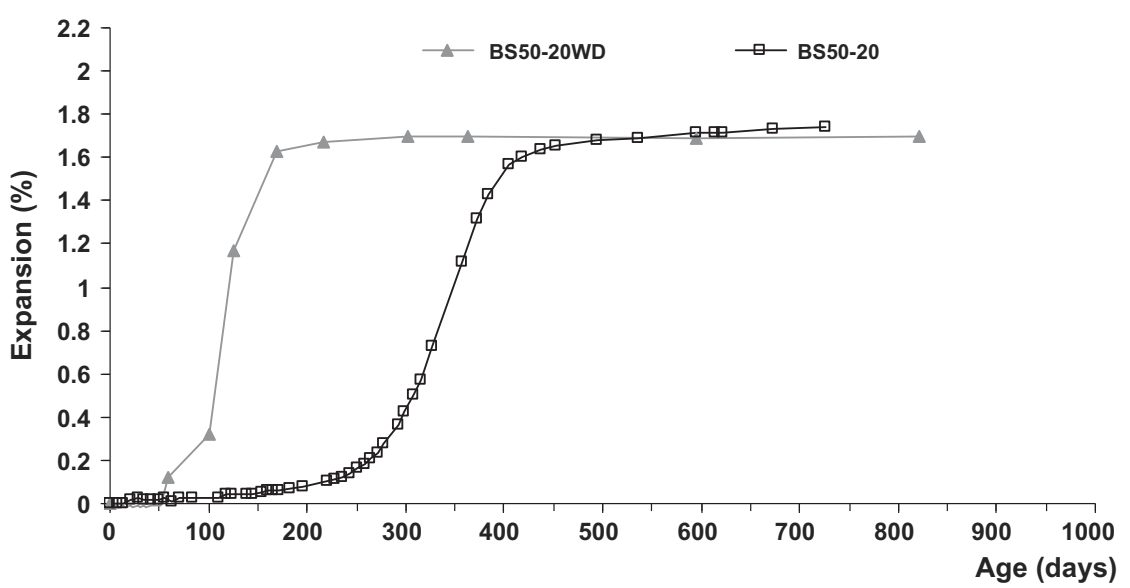

Figure 3. Length variations of the mortars prepared with BS50 cement and subjected to with and without wetting-drying cycles. 


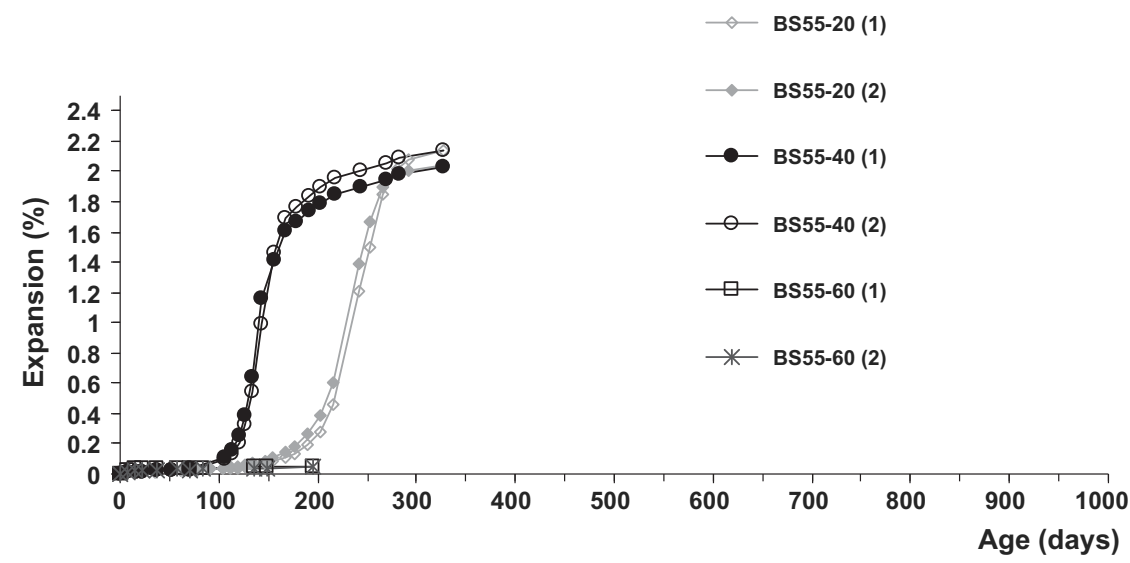

Figure 4. Length variations of the BS55 mortars cured continuously in water at 20,40 and $60^{\circ} \mathrm{C}$.

Figure 5 shows that the mortars cured in RW (BS55-20RW) develop expansions more quickly than the mortars that remain immersed continuously in the same curing water. Moreover, it seems that the ultimate expansions are equivalent in both cases. The preceding discussion on the effect of the cure temperature showed that the acceleration of the expansions with the increase of cure temperature could be due to modifications of the ionic transfers (and, in particular, of alkalis). In this case, the renewal of the curing water increases the concentration gradients between the mortar and the curing water and also accelerates the leaching of the ionic species contained in the mortar, in particular, the alkalis that can be favourable for DEF.

\section{Conclusions}

The results presented in this article lead to the following principal conclusions:

(1) As shown in the literature, the chemical composition of cement is one of the main parameters controlling the appearance of DEF. The comparisons between the various mixtures studied allow the importance of the various parameters intervening in the appearance and the development of this pathology to be graded:

- for cements with high $\mathrm{C}_{3} \mathrm{~A}$ and $\mathrm{SO}_{3}$ contents, the alkali content is essential and a weak variation in this content can allow or prevent the appearance of DEF;

- moreover, contrary to common belief, the $\mathrm{C}_{3} \mathrm{~A}$ content does not seem to be a limiting factor in the appearance of this pathology. It appears that the $\mathrm{C}_{3} \mathrm{~A}$ content influences the ultimate value of expansions but also that the development of DEF remains possible in spite of very low $\mathrm{C}_{3} \mathrm{~A}$ contents $(<5 \%)$.

(2) An increase in the $\mathrm{W} / \mathrm{C}$ ratio $(\mathrm{W} / \mathrm{C}>.50)$ accelerates the appearance of expansion and this acceleration is more significant when the $\mathrm{W} / \mathrm{C}$ ratio is high. Moreover, this increase in $\mathrm{W} / \mathrm{C}$ ratio (at least up to a ratio equal to .60) does not seem to have an influence on the ultimate value of expansion. 


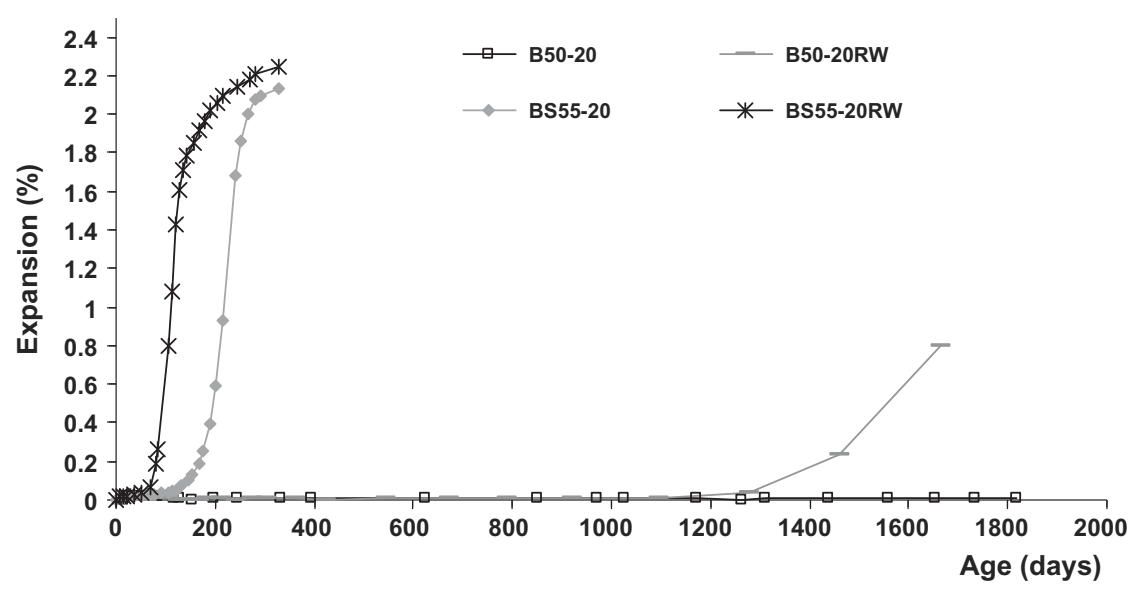

Figure 5. Length variations of the B50 and BS55 mortars cured in RW and in non-RW.

(3) The study of the effects of the wetting-drying cycles on the appearance of DEF leads to the following conclusions:

- preliminary microcracking induced by these wetting-drying cycles significantly accelerates the appearance of expansion, which confirms the data of the literature on the subject;

- the results obtained confirm that microcracking of the samples is not a necessary condition for DEF since it also develops (but later) in mortars not subjected to these wetting-drying cycles.

(4) The temperature of the curing water significantly influences the appearance of DEF. The reactions (and consequently expansion) start more quickly when the temperature of the curing water is higher. However, there is a maximum temperature $\left(60^{\circ} \mathrm{C}\right)$ from which the reactions seem to be slowed down or even stopped (ettringite destabilisation).

(5) The renewal of the curing water accelerates the appearance of DEF. A study over more than five years showed, in one case, that the renewal of the curing water led to a late start of DEF (fouryears), whereas the same mixture cured continuously in water that was not renewed still had not expanded after more than five years.

The results presented in this article confirm certain data of the literature and bring new elements, in particular, on the effect of the water renewal. The discussions show that the effects of the parameters studied (W/C ratio, wetting-drying cycles and curing conditions) could be explained by various phenomena but only one is common to all these parameters: the more favourable conditions are ionic and hydrous transfers (and in particular the fast leaching of alkalis), leading to the start of early expansion. Although that does not constitute a proof, it seems that the leaching of alkalis can be considered as a trigger for this pathology, as suggested by Diamond (2000). To better understand the phenomena and clear the doubt about the exact role played by the leaching of alkalis, it would be necessary to make thorough studies of the ionic exchanges which occur during the curing of DEF-affected specimens. 


\section{References}

Aubert, J. E., Escadeillas, G., \& Leklou, N. (2009). Expansion of five years old mortars attributable to DEF: Relevance of the laboratory studies on DEF? Construction and Building Materials, 23, 3583-3585.

Brunetaud, X. (2005). Etude de l'influence de différents paramètres et de leurs interactions sur la cinétique et l'amplitude de la réaction sulfatique interne au béton [A study of the influence of several parameters and their interactions on the kinetic and range of the internal sulphate reaction in concrete] (Ph.D. thesis). Ecole Centrale des Arts et Manufactures.

Brunetaud, X., Linder, R., Divet, L., Duragrin, D., \& Damidot, D. (2007). Effect of curing conditions and concrete mix design on the expansion generated by delayed ettringite formation. Materials and Structures, 40, 567-578.

Brown, P. W., \& Bothe, J. V. Jr. (1993). The stability of ettringite. Advances in Cement Research, $5,47-63$.

Collepardi, M. (1997). A holistic approach to concrete damage induced by delayed ettringite formation. Proceedings of fifth CANMET/ACI International Conference on Superplasticizers and Other Chemical Admixtures in Concrete, Rome, Italy.

Collepardi, M. (1999). Damage by delayed Ettringite formation - a holistic approach and new hypothesis, Concrete International, 21, 69-74.

Damidot, D., \& Glasser, F.-P. (1992). Thermodynamic investigation of the $\mathrm{CaO}-\mathrm{Al}_{2} \mathrm{O}_{3}-\mathrm{CaSO}_{4}-$ $\mathrm{H}_{2} \mathrm{O}$ system at $50^{\circ} \mathrm{C}$ and $85^{\circ} \mathrm{C}$. Cement and Concrete Research, 22, 1179-1191.

Damidot, D., \& Glasser, F.-P. (1993). Thermodynamic investigation of the $\mathrm{CaO}-\mathrm{Al}_{2} \mathrm{O}_{3}-\mathrm{CaSO}_{4}-$ $\mathrm{H}_{2} \mathrm{O}$ system at $25^{\circ} \mathrm{C}$ and the influence of $\mathrm{Na}_{2} \mathrm{O}$. Cement and Concrete Research, 23, 221-238.

Diamond, S. (2000). The relevance of laboratory studies on delayed ettringite formation to DEF in field concretes. Cement and Concrete Research, 30, 1987-1991.

Divet, L., \& Randriambololona, R. (1998). Delayed ettringite formation: The effect of temperature and basicity on the interaction of sulphate and $\mathrm{C}-\mathrm{S}-\mathrm{H}$ phase. Cement and Concrete Research, $28,357-363$.

Divet, L. (2001). Les réactions sulfatiques internes au béton: contribution à l'étude des mécanismes de la formation différée de l'ettringite [Sulphatic internal reactions to concrete: Contribution to the study of mechanisms the delayed formation of ettringite] ( $\mathrm{Ph} . \mathrm{D}$. thesis). Laboratoire Central des Ponts et Chaussées.

Escadeillas, G., Aubert, J.-E., Segerer, M., \& Prince, W. (2007). Some factors affecting delayed ettringite formation in heat-cured mortars. Cement and Concrete Research, 37, 1445-1452.

Famy, C. (1999). Expansion of heat-cured mortars (Thesis). Department of Materials, Royal School of Mines, Imperial College of Sciences, Technology and Medecine, London.

Famy, C., Scrivener, K. L., Atkinson, A., \& Brough, A. R. (2001). Influence of the storage conditions on the dimensional changes of heat-cured mortars. Cement and Concrete Research, 31, 795-803.

Fu, Y., Xie, P., Gu, P., \& Beaudoin, J. J. (1994). Significance of pre-existing cracks on nucleation of secondary ettringite in steam cured cement paste. Cement and Concrete Research, 24, $1015-1024$.

Fu, Y., Ding, J., \& Beaudoin, J. J. (1997). Expansion of Portland cement mortar due to internal sulfate attack. Cement and Concrete Research, 27, 1299-1306.

Ghorab, H. Y. (1999). Review of ettringite - monophase relationships in Portland cement systems. Ettringite the Sometimes Host of Destruction ACI International, SP 177-5, 65-79.

Grattan-Bellew, P. E., Beaudoin, J. J., \& Vallée, V.-G. (1998). Effect of aggregate particle size and composition on expansion of mortar bars due to delayed ettringite formation. Cement and Concrete Research, 28, 1147-1156.

Heinz, D., \& Ludwig, U. (1985). Mechanism of subsequent ettringite formation in mortars and concrete after heat treatment. Proceedings of 8th International Congress on the Chemistry of Cement, Rio de Janeiro, 5, 189-194.

Heinz, D., Kalde, M., Ludwig, U., \& Ruediger, I. (1999). Present state of investigation on damaging late ettringite formation (DLEF) in mortars and concretes. Ettringite the Sometimes Host of Destruction ACI International, SP 177-1, 1-14.

Hime, W. G., \& Marusin, S. (1999). Delayed ettringite formation: Many questions and some answers. Ettringite the Sometimes Host of Destruction ACI International, SP 177-1, 199-206.

Kelham, S. (1996). The effect of cement composition and fineness on expansion associated with delayed ettringite. Cement and Concrete Composite, 18, 171-179. 
Kelham, S. (1999). The influence of cement composition on the volume stability of mortars. Ettringite the Sometimes Host of Destruction, ACI International, SP 177-1, 27-45.

LCPC. (2007). Méthode d'essai ${ }^{\circ} 66$ : réactivité d'un béton vis-à-vis d'une reaction sulfatique interne [Concrete reactivity to internal sulfate attack. Performance test], LCPC, Réf. ATILH n ${ }^{\circ}$ 46062.

Leklou, N., Aubert, J. E., \& Escadeillas, G. (2009). Microscopic observations of samples affected by the delayed ettringite formation (DEF). Materials and Structures, 42, 1369-1378.

Leklou, N., Aubert, J. E., \& Escadeillas, G. (2012). Effect of wetting-drying cycles on mortar samples affected by DEF. European Journal of Environmental and Civil Engineering, 16, $582-588$.

Moranville, M. (1995). Implications of curing temperatures for durability of cement based systems, Curing temperatures and durability. Materials research society, fall meeting 1995, seminar on mechanism of chemical degradation of cement - based systems, 1-8.

Odler, I., \& Chen, Y. (1995). Effect of cement composition on the expansion of heat-cured cement pastes. Cement and Concrete Research, 25, 853-862.

Ouyang, C., Nanni, A., \& Chang, W. F. (1988). Internal and external sources of sulfate ions in Portland cement mortar: Two types of chemical attack. Cement and Concrete Research, 18, 699-709.

Pavoine, A. (2003). Evaluation du potentiel de réactivité des bétons vis-à-vis de la formation différée de l'ettringite [Evaluating the reactivity potential of concrete to delayed ettringite formation] (Ph.D. thesis). Université Pierre et Marie Curie - Paris VI.

Petrov, N. (2003). Combined effect of different factors on concrete expansion due to DEF (Thèse de doctorat, Ph.D. Thesis). Université de Sherbrooke.

Petrov, N., \& Tagnit-Hamou, A. (2004). Is microcracking really a precursor to delayed ettringite formation and consequent expansion? ACI materials journal, 101, 442-447.

Ramlochan, T., Zacarias, P., Thomas, M. D. A., \& Hooton, R. D. (2003). The effect of pozzolans and slag on the expansion of mortars cured at elevated temperature: Part I: Expansive behaviour. Cement and Concrete Research, 33, 807-814.

Ramlochan, T., Thomas, M. D. A., \& Hooton, R. D. (2004). The effect of pozzolans and slag on the expansion of mortars cured at elevated temperature: Part II: Microstructural and microchemical investigations. Cement and Concrete Research, 34, 1341-1356.

Sahu, S., \& Thaulow, N. (2004). Delayed ettringite formation in Swedish concrete railroad ties. Cement and Concrete Research, 34, 1675-1681.

Scrivener, K. L., \& Lewis, M. C. (1999). Effect of heat curing on expansion of mortars and composition of calcium silicate hydrate gel. Ettringite the Sometimes Host of Destruction, ACI International, SP 177-1, 93-104.

Scrivener, K.-L., \& Skalny, J. (2005). Conclusions of the international RILEM TC 186-ISA workshop on internal sulfate attack and delayed ettringite formation (4-6 September 2002, Villars, Switzerland). Materials and Structures, 38, 659-663.

Stark, J., \& Bollmann, K. (1992). Investigation into delayed ettringite formation in concrete. Proceedings of the 9th International Congress on the Chemistry of Cement, vol. 5, New Delhi, India, 348-354.

Taylor, H.-F.-W., Famy, C., \& Scrivener, K.-L. (2001). Delayed ettringite formation. Cement and Concrete Research, 31, 683-693.

Yang, R., Lawrence, C. D., \& Sharp, J. H. (1999). Effect of type of aggregate on delayed ettringite formation. Advances in Cement Research, 11, 119-132. 